\title{
Partial Purification of Alkaline Protease as Thrombolytic Agent from Mutant Strain Bacillus licheniformis EMS250-0-1
}

\author{
Md. Asad uz Zaman ${ }^{1}$, Md. Arafat Al Mamun², Shakila Nargis Khan ${ }^{3}$, \\ Md. Mozammel Hoq ${ }^{3}$ and Md. Abdul Mazid ${ }^{1}$ \\ ${ }^{1}$ Department of Pharmaceutical Chemistry, Faculty of Pharmacy, University of Dhaka, \\ Dhaka-1000, Bangladesh \\ ${ }^{2}$ Centre for Advanced Research in Sciences, University of Dhaka, Dhaka-1000, Bangladesh \\ ${ }^{3}$ Department of Microbiology, University of Dhaka, Dhaka-1000, Bangladesh
}

Received: July 31, 2016; Accepted: September 18, 2016; Published (web): December 27, 2016

\begin{abstract}
Thrombosis leads to myocardial infarction, stroke and other cardiovascular complications. Microbial thrombolytic agents such as urokinase, streptokinase etc. are used to treat complications related to thrombosis. To search for new microbial enzymes as thrombolytics having better efficacy and specificity, Bacillus licheniformis EMS-O-1 mutant strain was cultured in modified urea-molasses media followed by purification using ammonium sulphate precipitation and ultrafiltration through centricon tube of 100 MWCO value. The yield of crude enzyme was $11129.14 \mathrm{U} / \mathrm{mg}$ and after purification $40180.46 \mathrm{U} / \mathrm{mg}$. Purification process increased the specific activity of purified enzyme to 12.28 fold with a recovery of $17.79 \%$. The purified enzyme was a serine protease with molecular weight of $25.5 \mathrm{kDa}$ as confirmed by irreversible inhibition of activity with phenylmethylsulfonyl fluoride (PMSF) followed by SDS-PAGE gel image and by LC-MS analyses. In vitro clot lysis assay of the purified enzyme exhibited $38.30 \%$ thrombolytic activity. The crude enzymes from the mutant strain EMS-O- 1 were found to be stable up to $50{ }^{\circ} \mathrm{C}$ and showed maximum stability between $\mathrm{pH}$ range 7.5 to 8.5 . These findings signify that proteases produced by B. licheniformis mutant have the potential to be developed as a viable thrombolytic agent.
\end{abstract}

Key words: Bacillus licheniformis; Protease; Purification; Thrombolytic activity

\section{INTRODUCTION}

Proteolytic enzymes or proteases are very important constituents in living systems. They are related in almost every aspects of life such as protein turnover, sporulation, germination, enzyme modification, blood clotting, tumor progression etc. ${ }^{1}$ Their industrial applications include detergents, food industry, leather industry, manufacture of aspartame etc. $^{2}$ Instead of complicated protein biology, proteases are relatively safe and well tolerated which enables their applications in thrombolysis, correction of coagulation disorders, sepsis, neuromascular problems, digestion, etc. ${ }^{1}$

Correspondence to: Md. Abdul Mazid

E-mail:ma.mazid@du.ac.bd

Dhaka Univ. J. Pharm. Sci. 15(2): 135-141, 2016 (December)
Formation of clots (thrombus) in blood vessels can lead to serious disease to human such as myocardial infarction and stroke. Drugs using fibrinolytic enzymes are the most effective methods in the treatment of thrombosis. ${ }^{3,4}$ A variety of fibrinolytic enzymes such as tissue plasminogen activator (t-PA), urokinase (u-PA), and bacterial plasminogen activator streptokinase have been extensively studied and used as thrombolytic agents. Their major functions have been described as plasminogen activators or plasmin-like proteases which can directly degrade fibrin or fibrinogen, thereby dissolving thrombi rapidly and completely.,

Over the last 10 years, several effective thrombolytic agents have been identified and characterized from microorganism. Therefore, 
microbial fibrinolytic enzymes, especially those from food-grade microorganisms, have the potential to be developed as functional food additives and drugs to prevent or cure thrombosis and other related diseases. $^{7-9}$ Fibrinolytic enzymes were successively discovered from different microorganisms, the most important among which is the genus Bacillus from traditional fermented foods. These bacterial strains have been found to effectively produce extracellular and intracellular proteases. Many previous researches have shown to successfully isolate and purify the fibrinolytic enzymes from Bacillus sp. for examples, Bacillus sp. strain CK 11-4 was discovered from traditional Korean fermented-soybean sauce, named Chung-Kook-Jang $^{10}$, Bacillus subtilis DC33 was isolated from Chinese traditional Douchi ${ }^{11}$ and Bacillus licheniformis $\mathrm{KJ}-31^{12}$ isolated from Korean traditional Jeot-gal. The physiochemical properties of these enzymes have been characterized, and their effectiveness in thrombolysis in vitro has been further evaluated.

Thrombolytic agents such as microbial streptokinase and urokinase, and recombinant tissue plasminogen activators such as altepase are used to dissolve the clots. ${ }^{13-15}$ Unfortunately, these agents are often expensive, thermolabile and produce undesirable side effects. Therefore, further research needs to be carried out to find new fibrinolytic enzyme as potential antithrombotic drug. Recently, proteases produced by Bacillus species have been identified to possess fibrinolytic and thrombolytic activities. ${ }^{16,17}$ These finding has opened a gateway to isolate newer thrombolytic agents from Bacillus species as future antithrombotic therapy. The present study has been designed to develop the process to produce and purify the proteases produced by Bacillus species obtained from different sources such as foods, soils, etc.

\section{MATERIALS AND METHODS}

Microorganism and culture. Bacillus licheniformis EMS-O-1, mutant of Bacillus species isolated from feather decomposed soil was used to purify the protease ${ }^{18}$ and stock culture was maintained at $-70^{\circ} \mathrm{C}$ in nutrient broth containing $10 \%$ glycerol. Initially, B. licheniformis EMS-O-1 was streaked onto TSA plates and incubated for 2 days at $37^{\circ} \mathrm{C}$ and then the organisms were transferred to screw cap test tubes containing $5 \mathrm{ml}$ sterile TSB and incubated overnight at $37^{\circ} \mathrm{C}$ and used as seed culture. Then seed culture was transferred in each $500 \mathrm{ml}$ Erlenmeyer flask containing $95 \mathrm{ml}$ of modified ureamolasses medium (10g molasses, $5 \mathrm{~g}$ urea, $5 \mathrm{~g}$

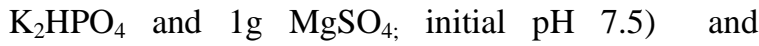
incubated at $37{ }^{\circ} \mathrm{C}$ and $150 \mathrm{rpm}$ in a thermostated orbital shaker for $48 \mathrm{~h}$.

Purification of enzyme. Alkaline protease rich culture supernatant was separated from biomass by centrifugation of ferment at 5,000 $\mathrm{g}$ for $10 \mathrm{~min}$. Then it was subjected to ammonium sulphate precipitation at a saturation level from $50 \%$ upto $80 \%(\mathrm{w} / \mathrm{v})$ followed by centrifugation at $10,000 \mathrm{~g}$ at $4^{\circ} \mathrm{C}$ for 30 minutes. The precipitate obtained was dissolved in 50 $\mathrm{mM}$ Tris-HCl buffer (pH 7.0). ${ }^{19,20}$ This partially purified enzyme was then concentrated by ultrafiltration passing through centricon tubes (Amicon ${ }^{\circledR}$, Millipore) $)^{21,22}$ of $100 \mathrm{kDa}$ MWCO and 30 kDa MWCO.

Estimation of extracellular soluble protein and protease activity. Concentration of extracellular soluble protein was estimated by Bradford method. ${ }^{23}$ Bovine serum albumin (BSA) was used as standard and absorbances were recorded at $595 \mathrm{~nm}$ using a spectrophotometer (GENESYS $^{\mathrm{TM}}$ 5, Thermo Scientific). The protein concentration was calculated by drawing a standard calibration curve of bovine serum albumin. On the other hand, protease activity was estimated by a modified procedure described by Krieger and Lockwood using azo-casein (Sigma, USA) as a substrate. ${ }^{24}$ For this study, $400 \mu \mathrm{l}$ of culture supernatant was mixed with $400 \mu \mathrm{l}$ of $1 \%$ Azo-casein solution in $0.05 \mathrm{mM}$ Tris-HCI buffer $\left(\mathrm{P}^{\mathrm{H}}\right.$ 8.5) and incubated for 1 hour at $37^{\circ} \mathrm{C}$ in a shaking water bath. After stopping the reaction with $135 \mu \mathrm{l}$ of $35 \%$ trichloroacetic acid (TCA), the mixture was kept for $10 \mathrm{~min}$ at $4{ }^{\circ} \mathrm{C}$ and then centrifuged at $10,000 \mathrm{~g}$ for $10 \mathrm{~min}$. The supernatant was mixed with $\mathrm{NaOH}$ $(1 \mathrm{M})$ at 1:1 ratio and absorbance was recorded at 
$440 \mathrm{~nm}$ immediately. A control reaction was carried out at the same time by adding TCA before mixing the culture supernatant with azo-casein solution. An increase in absorbance of 0.01 at $440 \mathrm{~nm}$ was considered as one unit of protease activity which reflected the amount of enzyme and expressed in $\mathrm{U} / \mathrm{ml}$. Specific activity (U/mg) was calculated from enzyme activity and extracellular protein concentration $(\mathrm{mg} / \mathrm{ml})$.

Protein molecular weight determination. Permeates from centricon tubes (both $100 \mathrm{kDa}$ MWCO and $30 \mathrm{kDa}$ MWCO) were separated by electrophoresis on sodium dodecyl sulphate polyacrylamide gel (SDS-PAGE) using $12 \%$ gradient polyacrylamide gel and 4\% polyacrylamide stacking gel. The gel sheet was then stained with coomassie brilliant blue (CBB) ${ }^{25,26}$ and molecular weight of the partially purified enzyme on gel image was estimated using Alpha View software. To further confirm, separated protein band was excised from the gel, destained and then extracted using buffer $5 \%$ formic acid/acetonitrile (1:2, v/v). The extracted protein was subjected to ESI LC/MS analysis (LC parameters: solvent-water/acetonitrile with $0.1 \%$ formic acid, flow rate $-0.5 \mathrm{ml} / \mathrm{min}$, Column- Poroshell 120 ECC18, Agilent Technologies, System: Shimazdu Prominance UFLC/UFLCxr; MS parameters: System: AB Sciex Triple TOF 5600, Scan for TOF MS: $600-3000 \mathrm{Da}){ }^{27}$

Stability of enzymes. Stability of crude protease was determined by pre-incubating the protease at different temperatures and $\mathrm{pH}$. To assess the thermal stability crude proteases were incubated at $25^{\circ} \mathrm{C}$, $30^{\circ} \mathrm{C}, 40^{\circ} \mathrm{C}, 50^{\circ} \mathrm{C}, 60^{\circ} \mathrm{C}$ and $70^{\circ} \mathrm{C}$ for $1 \mathrm{hr}$. On the other hand, to assess the $\mathrm{pH}$ stability crude protease was incubated by diluting the enzyme in different buffers (pH 5.0 - 11.0) and incubated for $1 \mathrm{hr}$ at room temperature. Buffers used for this study were citric acid buffer (pH 5.0 - 6.0), phosphate buffer (pH 7.0 $8.0)$, carbonate buffer ( $\mathrm{pH} 9.0$ - 10) and sodium bicarbonate buffer $(\mathrm{pH} 11)$. After incubation, the enzyme activity was assayed as described above.

Thrombolytic activity assay. Thrombolytic activity of the partially purified enzymes were assessed in vitro by clot lysis moethod. Streptokinase was used as standard and PBS was used as control. ${ }^{28}$ Briefly, fresh venous blood was transferred in different pre-weighed microcentrifuge tube (500 $\mu \mathrm{l} /$ tube) and allowed to form clot incubateing at $37^{\circ} \mathrm{C}$ for 45 minutes. Then serum was completely removed from each tube and weight of the clot in each tube was calculated. Then, $100 \mu \mathrm{l}$ of partially purified enzymes were added in each tube. Commercially available streptokinase and PBS were used as control. All tubes were incubated at $37^{\circ} \mathrm{C}$ for 90 minutes for the lysis of clot. Then lysed clot was removed from each tube and weighed again. The percentage of weight loss in each tube was calculated. The assay was repeated thrice and the values were expressed as mean \pm SEM. The significance between $\%$ clot lysis by streptokinase and purified protease was analyzed by $t$-test.

\section{RESULTS AND DISCUSSION}

The production method yielded crude enzyme with specific activity of $1129.14 \mathrm{U} / \mathrm{mg}$ from the Bacillus sp. mutant strain EMS250-O-1 and total activity was found to be $405900.00 \mathrm{U}$ (Table 1). The culture supernatant of EMS250-O-1 mutant was subjected to ammonium sulphate precipitation at $60 \%$ saturation which concentrated the proteins with specific activity of $40180.46 \mathrm{U} / \mathrm{mg}$, while total activity enzyme was estimated as $135916.50 \mathrm{U}$. The initial total protein content was estimated $359.52 \mathrm{mg}$ which reduced to $41.54 \mathrm{mg}$ after salting out. Further ultra filtration with $100 \mathrm{kDa}$ MWCO centricon tube reduces the protein concentration to $1.78 \mathrm{mg} / \mathrm{ml}$. This purification process increased the specific activity by 12.28 folds with a recovery of $17.80 \%$ (Table 1 ). The successive purification through salt precipitation and ultrafiltration process increased the specific activity to $3272.75 \mathrm{U} / \mathrm{mg}$ and $40180.46 \mathrm{U} / \mathrm{mg}$, respectively (Table 1).

The total protein content of the culture supernatant decreased when the crude enzymes were subjected to ammonium sulphate precipitation. The purified enzyme obtained after ammonium sulphate precipitation and ultrafiltration through centricon 
tube suggested that the utrafiltration could retain the specific molecular weight proteins suggesting that our approach for purification was effective. The purified protease was identified as serine protease by irreversible inhibition of activity with phenylmethylsulfonyl fluoride (PMSF).

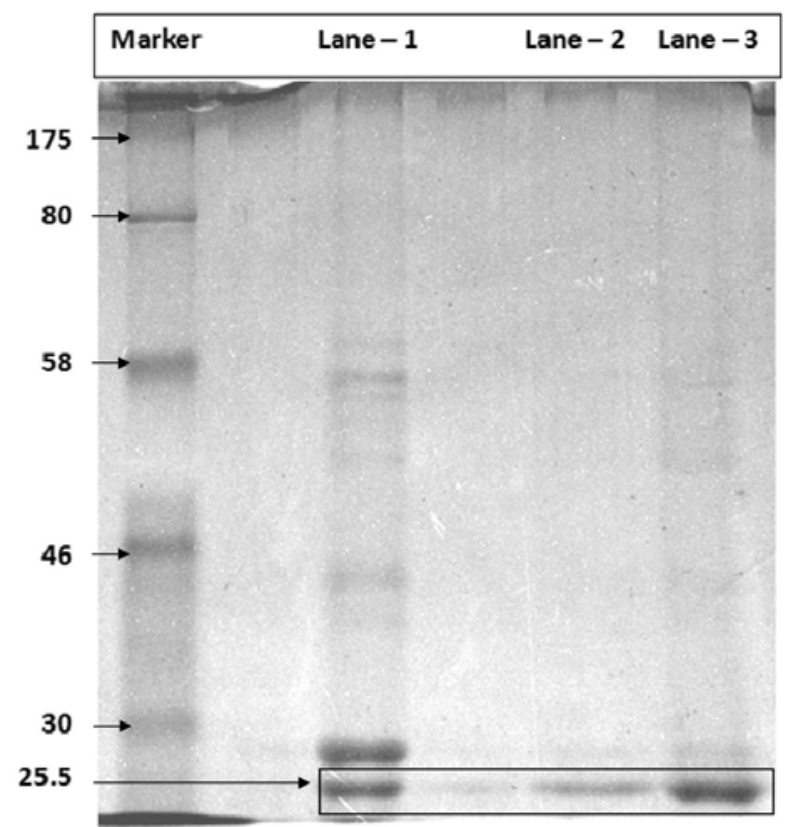

Figure 1. Molecular weight determination of the purified protease enzyme from Bacillus sp. EMS250-O-1 by polyacrylamide gel electrophoresis. Lane 1: Ammonium sulfate precipitated enzyme, Lane 2: $100 \mathrm{kDa}$ Centricon tube retained enzyme, Lane 3: $30 \mathrm{kDd}$ MWCO Centricon tube permeate enzyme.

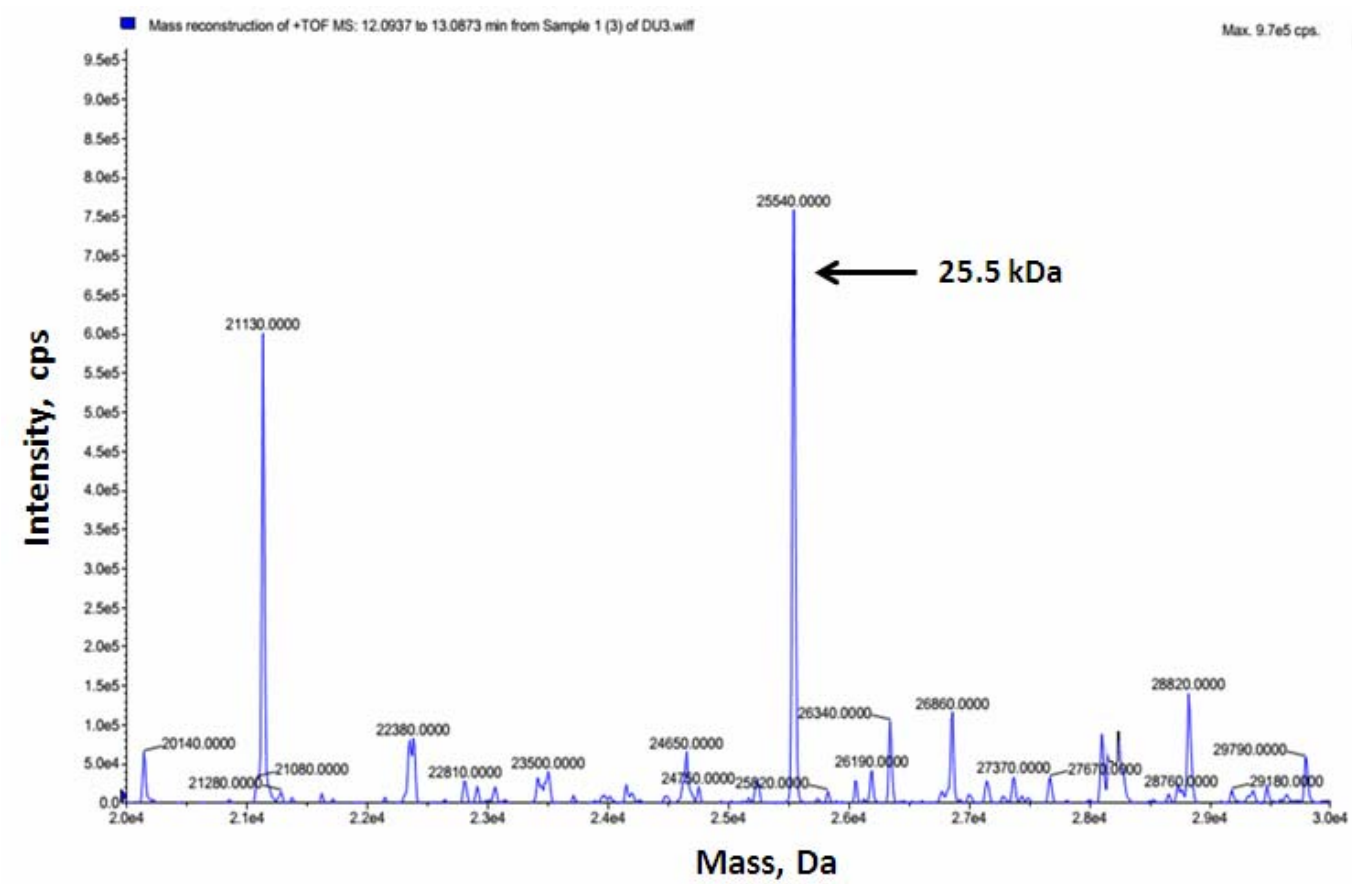

Figure 2. Determination of molecular weight of partially purified proteases resolved on SDS-PAGE by LC-MS analysis. Intense signal at $25.5 \mathrm{kDa}$ and less intense signal at $21.1 \mathrm{kDa}$ indicating existence of two proteins which fairly converge to the molecular range of protease secreted from bacteria. 

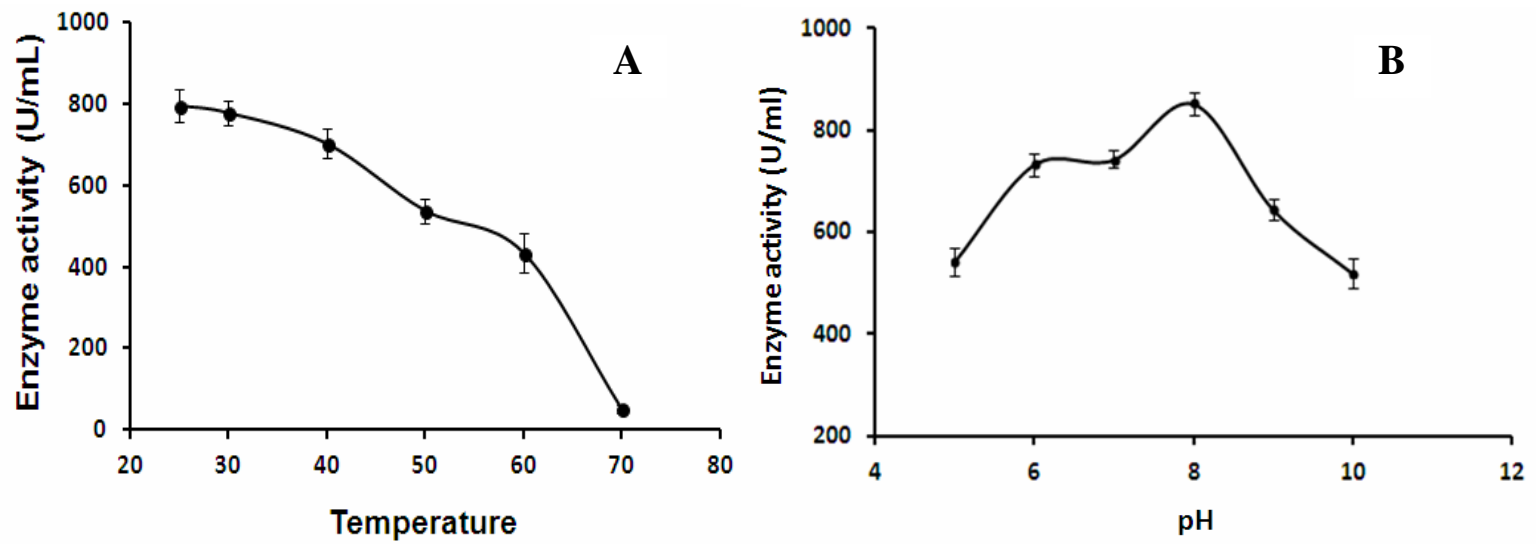

Figure 3. Effect of temperature (A) and $\mathrm{pH}(\mathrm{B})$ on the stability of crude alkaline protease

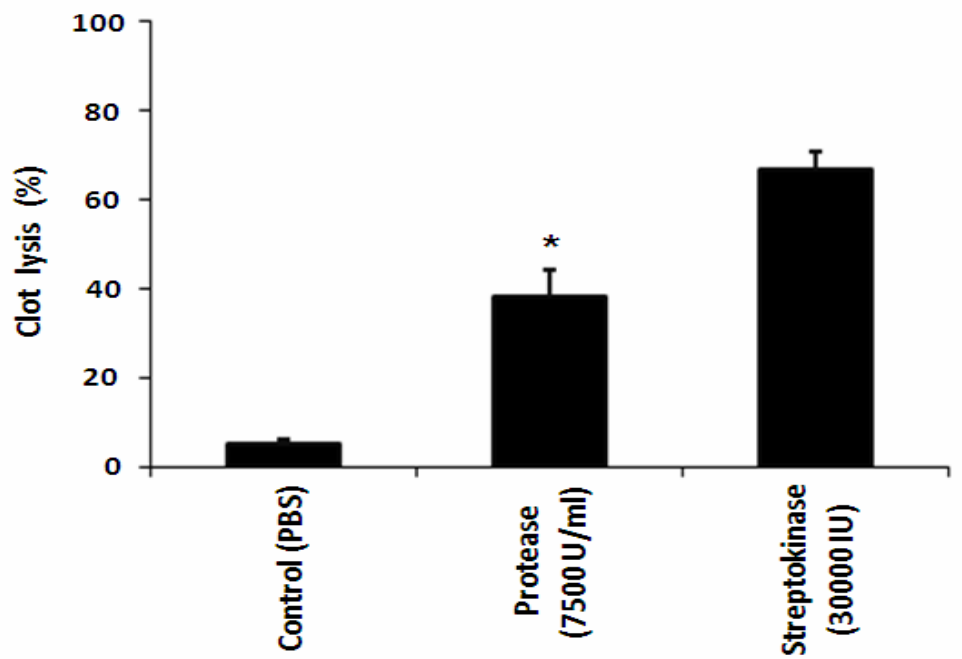

Figure 4. Thrombolytic effects of purified protease from Bacillus sp. mutant strain EMS250-O-1 with streptokinase and PBS. Data represented as mean \pm SEM of three independent experiments. ${ }^{*} \mathrm{P}<0.001$ vs control (phosphate buffered saline).

Table 1. The purification steps of thrombolytic protease enzyme from mutant strain B. licheniformis EMS250-0-1.

\begin{tabular}{lccccc}
\hline Purification step & Total activity $(\mathrm{U})$ & Total protein $(\mathrm{mg})$ & $\begin{array}{c}\text { Specific activity } \\
(\mathrm{U} / \mathrm{mg})\end{array}$ & $\begin{array}{c}\text { Purification fold } \\
\text { Recovery } \\
(\%)\end{array}$ \\
\hline $\begin{array}{l}\text { Crude enzyme } \\
\begin{array}{l}\text { Ammonium Sulfate } \\
\text { precipitated enzyme }\end{array}\end{array}$ & 405900.00 & 359.52 & 1129.14 & 1 & 100 \\
$\begin{array}{l}100 \text { kd Centricon tube } \\
\text { permeate }\end{array}$ & 725916.50 & 41.54 & 3272.75 & 2.90 & 33.49 \\
\end{tabular}

Permeates from 100 kDa MWCO tube retained enzymes was revealed by SDS-PAGE analysis of salt precipitated enzyme followed by gel image analysis (Figure 1). The presence of approximately $25.5 \mathrm{kDa}$ protein was confirmed when permeates from $30 \mathrm{kDa}$ MWCO centricon tube was analyzed by SDS-PAGE. Furthermore, gel digestion followed by LC-MS analysis as described above confirmed the molecular weight of the partially purified enzyme from EMS250-O-1 mutant (Figure 2). The separated protein band of $25.5 \mathrm{kDa}$ on gel, though contained multiple proteins which fairly converge to the molecular range of serine protease, secreted from the strain. Based on SDS-PAGE and LC-MS analysis, it was observed that the estimated molecular weight of partially purified targeted thrombolytic protein is 
$25.5 \mathrm{kDa}$ approximately. The purified enzyme was tested for its thrombolytic activity as described under materials and methods.

The stability study of the protease from Bacillus $s p$. mutant strain EMS-O-1 showed that the activity remained more or less stable up to $50{ }^{\circ} \mathrm{C}$, after which the activity began to decrease slowly. Activity was found to be deceased rapidly at $55{ }^{\circ} \mathrm{C}$ (Figure 3A). The enzyme was found to be highly stable at $25{ }^{\circ} \mathrm{C}$ as it showed highest activity $(793 \mathrm{U} / \mathrm{ml})$ at this temperature. On the other hand, the enzyme showed highest stability between the $\mathrm{pH}$ range 7.5 to 8.5 . The highest activity obtained at this point of highest stability was $853.0 \mathrm{U} / \mathrm{ml}$ (Figure 3B). The stability of the enzyme was found to be decreased beyond this $\mathrm{pH}$ range.

Thrombolytic activity assay of the partially purified protease enzyme showed that the average \% of clot lysis by the enzyme obtained from Bacillus $s p$. mutant strain EMS250-O-1 were $32.58 \pm 2.88 \%$, $43.11 \pm 3.25 \%$ and $38.34 \pm 2.04 \%$, respectively for three independent assays carried out in triplicate (Figure 4) with an average activity of $38.30 \%$. This data is an indication of thrombolytic activity of the purified protein. Previous work on purification and characterization of thrombolytic enzymes from bacterial sources reported that the purified thrombolytic enzyme has a molecular weight within the range of 20-45 $\mathrm{kDa}^{1,12}$

\section{CONCLUSION}

A number of microbial enzymes have been reported to have thrombolytic activities. Among them streptokinase (a bacterial protein from beta haemolytic E. coli) is used in practice as a thrombolytic agent. The beneficial effects and biochemical mechanisms of thrombolytic therapy have been established and search for new and alternative therapy is still continuing due to diversity of natural resources. Bacillus species have been recognized as source of protease enzymes having thrombolytic activities. ${ }^{1,11,12}$ The nature of thrombolytic activity of microbial proteases in clot is similar to that of streptokinase. From out present study, it is evident that the thrombolytic proteases obtained from B. licheniformis strain EMS250-O-1 has significant clot lysis activity. Further research can be conducted to develop a novel and economically viable therapeutic thrombolytic agents using these thrombolytic proteases.

\section{ACKNOWLEDGEMENTS}

The authors gratefully acknowledges the Ministry of Science and Technology, Government of the People's Republic of Bangladesh for funding support under special allocation for Science and Technology Programme 2015-2016 (Sl.217, Gr. Sl. 91,MEDI;S). Authors are also thankful to Incepta Pharmaceuticals Ltd., Ashulia, Dhaka, Bangladesh for providing Laboratory support for LC-MS analysis.

\section{CONFLICT OF INTEREST}

We declare no conflict of interest.

\section{REFERENCES}

1. Craik, C.S., Page, M.J. and Madison, E.L. 2011. Proteases as therapeutics. Biochem J. 435, 1-16

2. Rao, C.S., Sathish, T., Pendyala, B. Kumar, T.P. and Prakasham R.S. 2009. Development of a mathematical model for Bacillus circulans growth and alkaline protease production kinetics. J. Chem. Technol. Biotechnol. 84, 302307.

3. Collen, D., Gold, H.K. 1990. New developments in thrombolytic therapy. Adv. Exp. Med. Biol. 281, 333-54.

4. Tough, J. 2005. Thrombolytic therapy in acute myocardial infarction. Nurs. Stand. 19, 55-64.

5. Lijnen, H.R.and Collen, D. 1995. Fibrinolytic agents: mechanisms of activity and pharmacology. Thromb. Haemost. 74, 387-90.

6. Collen, D. and Lijnen, H.R. 2005. Thrombolytic agents. Thromb. Haemost. 93, 627-630.

7. Sumi, H., Hamada, H., Tsushima, H., Mihara, H. and Muraki, H. 1987. A novel fibrinolytic enzyme (nattokinase) in the vegetable cheese Natto; a typical and popular soybean food in the Japanese diet. Experientia 43, 1110-1111.

8. Kim, S.H. and Choi N.S. 2000. Purification and characterization of subtilisin DJ-4 secreted by Bacillus sp. strain DJ-4 screened from Doen-Jang. Biosci. Biotechnol. Biochem. 64, 1722-1725. 
9. Peng, Y., Huang, Q., Zhang, R.H. and Zhang Y.Z. 2003. Purification and characterization of a fibrinolytic enzyme produced by Bacillus amyloliquefaciens DC-4 screened from douchi, a traditional Chinese soybean food. Comp. Biochem. Physiol. Biochem. Mol. Biol. 134, 45-52.

10. Kim, W., Choi, K., Kim, Y., Park, H., Choi J., Lee Y., Oh, H., Kwon I. and Lee S. 1996. Purification and characterization of a fibrinolytic enzyme produced from Bacillus sp. strain CK 11-4 screened from Chungkook-Jang. Appl. Environ. Microbiol. 62, 1488-2482.

11. Wang, C.T., Ji, B.P., Li, B., Nout, R, Li, P.L., Ji, H. and Chen, L.F. 2006. Purification and characterization of a fibrinolytic enzyme of Bacillus subtilis DC33, isolated from Chinese traditional Douchi. J. Ind. Microbiol. Biotechnol. 33, 750-758.

12. Hwang, K.J., Choi, K.H., Kim, M.J., Park, C.S. and Cha, J. 2007. Purification and characterization of a new fibrinolytic enzyme of Bacillus licheniformis $\mathrm{KJ}-31$, isolated from Korean traditional Jeot-gal. J. Microbiol. Biotechnol. 17, 1469-1476.

13. Reddy, D.S. 1998. Newer thrombolytic drugs for acute myocardial infarction. Indian J. Exp. Biol. 36, 1-15.

14. Chang, C.T., Fan, M.H., Kuo, F.C. and Sung, H.Y. 2000. Potent fibrinolytic enzyme from a mutant of Bacillus subtilis IMR-NK1”. J. Agric. Food Chem. 48, 3210-3216.

15. Grunwald, M.R. and Hofmann, L.V. 2004. Comparison of urokinase, alteplase and reteplase for catheter-directed thrombolysis of deep venous thrombosis. J. Vasc. Interv. Radiol. 15, 347-352.

16. Balami, J.S., Chen, R., Sutherland, B.A., Buchan, A.M. 2013. Thrombolytic agents for acute ischaemic stroke treatment: the past, present and future. CNS Neurol. Disord. Drug Targets. 12, $145-154$

17. Wang, W., Li, M., Chen, Q. and Wang, J. 2015. Hemorrhagic transformation after tissue plasminogen activator reperfusion therapy for ischemic stroke: mechanisms, models, and biomarkers. Mol. Neurobiol. 52, 1572-1579.
18. Hoq, M.M., Siddiquee, K.A.L., Kawasaki, H. and Seki, T. 2005. Keratinolytic activity of some newly isolated Bacillus species. J. Biol. Sci. 5, 193-200.

19. Dawson, R.M.C., Elliott, D.C., Elliott, W.H. and Jones, K.M. eds. 1986. Data for biochemical research. 3rd ed. Clarendon Press. Oxford, United Kingdom.

20. Taylor, J.F. 1953. The isolation of proteins. In The proteins: Chemistry, biological activity, and methods. part A (eds. H. Neurath and K.C. Bailey), 2-72, Academic Press, New York.

21. Maity, G., Mandal, S., Chatterjee, A., Bhattacharyya, D. 2007. Purification and characterization of a low molecular weight multifunctional cytotoxic phospholipase A2 from Russell's viper venom. J. Chromatogr B Analyt. Technol. Biomed. Life Sci. 845, 232-43.

22. Guerrieri, N., Scippa, S., Maietti, M., de Vincentiis, M. and Cerletti, P. 2000. Protease activity in fractionated blood cells of the vanadium accumulating ascidian Phallusia mammillata. Comp. Biochem. Physiol. A Mol. Integr. Physiol. 125, 445-50.

23. Bradford, M.M. 1976. A rapid and sensitive method for the quantitation of microgram quantities of protein utilizing the principle of protein-dye binding. Anal. Biochem. 72, 248-254.

24. Kreger, A. and Lockwood, D. 1981. Detection of extracellular toxin produced by Vibrio vulnificus. Infect. Immun. 33, 588590.

25. Laemmli, U. 1970. Cleavage of structural protein during the assembly of the head of bacteriophage T4. Nature. 227, 680685.

26. Merril, C.R. 1990. Gel staining techniques. Methods in Enzymology. 182, 477-488.

27. Shevchenkom, A., Tomasm, H., Havlism, J., Olsen, J.V. and Mann, M. 2006. In-gel digestion for mass spectrometric characterization of proteins and proteomes. Nat. Protoc. 1, 2856-2860.

28. Al-Mamun, M.R., Amrin, N., Begum, J. and Mazid, M.A. 2012. Thrombolytic activity of some spices and plants available in Bangladesh. Thai J. Pharmaceut. Sci. 36, 72-77. 